\title{
ANALISIS KESESUAIAN LAHAN UNTUK PENGEMBANGAN KOMODITAS KOPI ARABIKA DI KABUPATEN SOLOK
}

\author{
Feri Arlius, Moh. Agita Tjandra, Delvi Yanti \\ Program Studi Teknik Pertanian, Fakultas Teknologi Pertanian, Universitas Andalas \\ Email:sipado@yahoo.com
}

\begin{abstract}
ABSTRAK
Kopi arabika merupakan jenis kopi dengan cita rasa terbaik dan komoditi unggulan yang memiliki nilai ekonomi relatif tinggi di pasar dunia. Indonesia merupakan salah satu negara penghasil kopi arabika terbaik dunia, tetapi Indonesia bukanlah negara penghasil terbesar di dunia. Kabupaten Solok memiliki ketinggian tempat atau elevasi antara 329 - 1.458 mdpl yang mana pada ketinggian tersebut tanaman kopi arabika dapat tumbuh dengan baik. Tujuan penelitian ini adalah mengidentifikasi lahan untuk pengembangan kopi arabika di Kabupaten Solok. Dalam mengidentifikasi lahan untuk kopi arabika dilakukan analisis ketersediaan lahan dan kesesuaian lahan menurut struktur FAO (1976) yang mana hanya lahan kelas S1 (sangat sesuai) dan S2 (cukup sesuai) saja yang direkomendasikan. Luas lahan tersedia yang diperoleh cukup luas yaitu 101.059,79 ha (30,55 \%) dari luas Kabupaten Solok. Luas kesesuaian lahan untuk pengembangan kopi arabika berdasarkan lahan tersedia yaitu seluas $84.943,22$ ha $(84,05 \%)$, dengan asumsi produktifitas kopi arabika 1 ton/ha/tahun Kabupaten Solok bisa menghasilkan kopi arabika sekitar 84.943,22 ton/tahun. Luas kesesuaian lahan akan bertambah $3.447,94$ ha $(3,41 \%)$ jika diberikan konservasi terasering pada kelerengan, sehingga luas kesesuaian lahan untuk pengembangan kopi arabika di Kabupaten Solok menjadi 88.391,16 ha (87,46\%) dari lahan tersedia.

Kata kunci-kopi arabika, kesesuaian lahan, Kabupaten Solok
\end{abstract}

\section{PENDAHULUAN}

Kopi arabika merupakan salah satu komoditas yang diprioritaskan pengembangannya oleh pemerintah Indonesia saat ini. Ekspor kopi arabika dari Indonesia sebagian besar dipasarkan ke segmen pasar khusus (kopi spesialti) karena mutu citarasanya khas dan digemari oleh para penikmat kopi di negara-negara konsumen utama. Di segmen spesialti harga kopi lebih mahal dan fluktuasinya tidak terlalu tajam, yang tentunya berdampak pada pendapatan petani dan devisa negara (Wahyudi, 2008; Saragih, 2010).

Kopi arabika merupakan jenis kopi dengan cita rasa terbaik dan komoditi unggulan yang memiliki nilai ekonomi yang relatif tinggi di pasar dunia. Harga di pasar global tergolong yang paling stabil, petani bisa menerima hingga mendekati $90 \%$ dari harga terminal New York atau London bila sistem tata niaganya dikelola secara tepat dan dukungan sistem global yang transparan. Kopi arabika juga sebagai penghasil devisa Negara di sub sektor perkebunan, sumber pendapatan petani dan penciptaan lapangan kerja. Sebagai negara penghasil kopi terbesar ketiga di dunia setelah Brasil dan Vietnam, Indonesia mampu memproduksi kopi arabika pada tahun 2012 mencapai lebih dari 147 ribu ton dengan luas lahan kopi arabika mencapai 0,30 juta Ha (Kementrian Perindustrian, 2013).

Jenis kopi di Indonesia secara garis besar terbagi menjadi 2 jenis yaitu kopi arabika dan kopi robusta dimana kopi arabika memiliki cita rasa dan harga lebih tinggi dari pada kopi robusta. Kopi yang beredar di dunia saat ini secara umum terbagi menjadi 70\% kopi arabika dan 30\% kopi robusta. Sedangkan di Indonesia sendiri produksi terbesar adalah kopi robusta $80 \%$ dan kopi arabika $20 \%$. Indonesia merupakan salah satu penghasil kopi arabika terbaik di dunia, meskipun bukan penghasil kopi arabika terbesar di dunia (Kementrian Perindustrian, 2013). Besarnya permintaan dunia dan penghasil terbaik akan kopi arabika merupakan peluang yang sangat baik untuk melakukan pengembangan agar Indonesia dapat menjadi produsen besar dan sentra kopi arabika dunia, maka dari itu pengembangan komoditas ini akan diawali di Kabupaten Solok Sumatera Barat.

Kabupaten Solok merupakan Kabupaten yang sangat berpotensi untuk pengembangan komoditi kopi arabika dengan daerah yang ketinggian tempat atau elevasi antara $329-1.458 \mathrm{~m}$ di atas permukaan laut dan luas $330.803 \mathrm{Ha}$ dengan luas perkebunan kopi $11.482 \mathrm{Ha}$, akan sangat menguntungkan untuk membuka lahan baru untuk komoditi yang banyak di sukai masyarakat ini. 
Dalam pengembangan kopi arabika di Kabupaten Solok mempunyai prospek yang baik, terutama terpenuhinya syarat tumbuh tanaman (tanah dan iklim), tersedianya lahan, sarana produksi dan tenaga kerja serta pemasaran hasil. Selain kondisi iklim yang sangat mendukung Kabupaten ini juga berpotensi menghasilkan kopi arabika speciality grade yaitu kopi yang memiliki kualitas terbaik dengan cita rasa yang khas berkualitas tinggi dan tentunya harus dengan pengolahan yang baik pula.

Salah satu cara yang digunakan untuk mengembangkan komoditas kopi arabika di Kabupaten Solok ini adalah dengan cara melakukan penambahan luas areal penanaman kopi arabika melalui proses analisis kesesuaian lahan, dan yang dimaksud dengan analisis kesesuaian lahan adalah analisis kecocokan dari sebidang lahan untuk tipe penggunaan tertentu. Analisis kesesuaian lahan ini nantinya dapat memberikan informasi tentang tingkat kesesuaian lahan, distribusi dan luasan, serta faktor pembatasnya sehingga dapat diketahui tindakan - tindakan yang perlu dilakukan dalam upaya perbaikan dan perluasan lahan pengembangan komoditas kopi arabika tersebut dengan menggunakan aplikasi dari software GIS. Selain itu juga pengembangan komoditas kopi arabika ini nantinya, diharapkan mendukung perencanaan pembangunan pertanian yang produktif, berdaya saing tinggi dan berkelanjutan serta dapat mendorong pertumbuhan perekonomian rakyat Kabupaten Solok. Tujuan penelitian ini adalah mengidentifikasi potensi lahan tersedia untuk pengembangan komoditas kopi arabika dan tingkat kesesuaiannya di Kabupaten Solok.

\section{METODOLOGI PENELITIAN}

\section{A. Lokasi dan Waktu}

Lokasi penelitian adalah Kabupaten Solok dan pengolahan data dilaksanakan di Laboratorium Manajemen Pertanian dan Informasi Geografis dan Laboratorium Teknik Sumber Daya Lahan dan Air Fakultas Teknologi Pertanian Universitas Andalas pada bulan Juli 2014 - September 2014.

\section{B. Alat dan Bahan}

Alat yang digunakan dalam pelaksanaan penelitian ini yaitu seperangkat komputer dengan software GIS digunakan sebagai Tools untuk mempermudah kerja dalam pengolahan data. Bahan yang digunakan dalam penelitian yaitu:

1. Peta Administrasi Kabupaten Solok, diperoleh dari Badan Pusat Statistik Kementan tahun 2010.

2. Peta Penggunaan Lahan Kabupaten Solok, diperoleh dari Badan Pengembangan dan Penelitian Sumberdaya Lahan Pertanian tahun 2011.

3. Peta Kawasan Hutan Kabupaten Solok, diperoleh dari Badan Pusat Statistik Kementan tahun 2010.

4. Peta Tanah Kabupaten Solok, diperoleh dari Badan Pengembangan dan Penelitian Sumberdaya Lahan Pertanian.

5. Citra SRTM (Shuttle Radar Topography Mission), diperoleh dari Badan Pengembangan dan Penelitian Sumberdaya Lahan Pertanian.

6. Data Curah hujan Kabupaten Solok, diperoleh dari PSDA Sumatera Barat.

\section{Prosedur Penelitian}

Dalam identifikasi potensi lahan tersedia untuk pengembangan kopi arabika di Kabupaten Solok dilakukan analisis ketersediaan lahan dan tingkat kelas kesesuaian lahan. Pengelolaan dan analisis dilakukan dengan menggunakan program GIS yang dikelola secara spasial. Tahap analisis sebagai berikut:

\section{Ketersediaan Lahan}

Dalam analisis ketersediaan lahan dilakukan pada peta kawasan hutan dan peta penggunaan lahan yang diperoleh dari BBSDLP dengan cara overlay. Hasil peta overlay dilakukan algoritma pada attribute table dengan parameter lahan tersedia adalah pada fungsi kawasan hutan yang dinyatakan pada fungsi kawasan Areal Penggunaan Lain (APL) dan Hutan Produkasi Konversi (HPK). Pada peta penggunaan lahan parameter yang digunakan sebagai lahan tersedia antara lain penggunaan semak belukar, belukar rawa, kebun, kebun campuran, hutan sekunder, dan lahan terbuka. Pada tabel atribut 
dilakukan pengolahan algoritma untuk menentukan ketersediaan lahan dengan Select by Attributes. Hasil dari algoritma analisis merupakan lahan yang tersedia untuk pengembangan suatu komoditas tanaman.

\section{Kesesuaian Lahan}

Metode yang digunakan dalam penentuan tingkat kelas kesesuaian lahan adalah metode skoring. Dalam menentukan tingkat kesesuaian lahan kopi arabika diperlukan peta ketinggian tempat, peta lereng, peta tanah, dan peta sebaran curah hujan di Kabupaten Solok. Peta kesesuaian lahan yang akan diperoleh adalah kesesuaian lahan aktual yang dilakukan pada kondisi penggunaan lahan sekarang (present land use), tanpa masukan perbaikan. Sebenarnya kelas kesesuaian lahan bisa ditingkatkan kelasnya dengan dengan melakukan perbaikan pada faktor pembatasnya, yang disebut sebagai kesesuaian lahan potensial.

\section{HASIL DAN PEMBAHASAN}

\section{A. Gambaran Umum Lokasi Penelitian}

Kabupaten Solok adalah salah satu Kabupaten di Provinsi Sumatera Barat, Indonesia. Pemekaran wilayah Kabupaten Solok pada akhir tahun 2003 telah melahirkan satu kabupaten baru yaitu Kabupaten Solok Selatan. Dengan tejadinya pemekaran ini berarti luas wilayah Kabupaten Solok mengalami pengurangan secara signifikan dari semula $708.402 \mathrm{Ha}\left(7.084,02 \mathrm{~km}^{2}\right)$ menjadi 330.803 Ha $\left(3.308,03 \mathrm{~km}^{2}\right)$. Secara geografis letak Kabupaten Solok berada antara $00^{\circ} 32^{\prime}{ }^{\prime} 14^{\prime \prime}$ dan $01^{0}$ $46^{\prime} 45^{\prime \prime}$ Lintang Selatan dan $100^{\circ} 25^{\prime}$ '00" dan $101^{\circ} 41^{\prime}$ 41" Bujur Timur. Topografi wilayah sangat bervariasi antara dataran, lembah dan berbukit-bukit dengan ketinggian antara 329 meter -1.458 meter di atas permukaan laut.

Wilayah Administratif Pemerintah Kabupaten Solok secara Yuridis Formil dibentuk dengan Undang Undang No.12 tahun 1956. Pada tahun 2001 melalui Perda No.4 tentang Pemerintahan Nagari dan Perda No.5 tentang Pemerintahan dan Pembentukan Kecamatan, maka Kabupaten Solok terdiri dari 19 Kecamatan, kemudian setelah pemekaran pada tahun 2003 jumlah Kecamatan di Kabupaten Solok menjadi 15 Kecamatan. Seperti yang terlihat pada Tabel 1.

Tabel 1. Luas Kecamatan yang terdapat pada Kabupaten Solok

\begin{tabular}{|c|c|c|c|c|c|}
\hline No & Kecamatan & $\begin{array}{l}\text { Luas } \\
\text { (Ha) }\end{array}$ & No & Kecamatan & $\begin{array}{l}\text { Luas } \\
\text { (Ha) }\end{array}$ \\
\hline 1 & Bukit sundi & $7.937,41$ & 9 & Lembang jaya & $5.640,84$ \\
\hline 2 & Danau kembar & $13.017,35$ & 10 & Lubuk sikarah & $3.711,06$ \\
\hline 3 & Gunung talang & $29.778,91$ & 11 & Pantai cermin & $23.261,53$ \\
\hline 4 & Hiliran gumanti & $22.525,03$ & 12 & Payung sekaki & $23.644,37$ \\
\hline 5 & Ix koto sungai lasi & $13.462,37$ & 13 & Tanjung harapan & $2.375,77$ \\
\hline 6 & Junjung sirih & $7.764,09$ & 14 & Tigo lurah bajanjang & $96.008,43$ \\
\hline 7 & Kubung & $19.811,16$ & 15 & $\mathrm{X}$ koto diatas & $20.147,42$ \\
\hline 8 & Lembah gumanti & $25.530,79$ & 16 & $\mathrm{X}$ koto singkarak & $16.186,45$ \\
\hline \multicolumn{5}{|c|}{ Total } & 330.803 \\
\hline
\end{tabular}

\section{B. Ketersediaan Lahan}

\section{Kawasan Hutan}

Dalam menentukan lahan tersedia, terlebih dahulu harus memperhatikan fungsi kawasan hutan, agar tidak terjadi kerusakan hutan dan keseimbangan kawasan hutan tetap terjaga. Fungsi kawasan hutan Kabupaten Solok yang diperoleh berdasarkan data dari Badan Pusat Statistik (BPS) Kementrian Pertanian tahun 2010. Dalam data tersebut terdapat 8 fungsi kawasan hutan di Kabupaten Solok. Persentase luasan masing- masing kawaasan hutan dapat dilihat pada Tabel 2. 
Tabel 2. Fungsi Kawasan Hutan Kabupaten Solok

\begin{tabular}{|c|c|c|}
\hline Fungsi Kawasan & Luas (Ha) & Persentase $(\%)$ \\
\hline Areal Penggunaan Lain & $118.413,2$ & 35,80 \\
\hline Cagar Alam & $47.115,65$ & 14,24 \\
\hline Hutan Lindung & $121.503,15$ & 36,73 \\
\hline Hutan Produksi & $8.156,29$ & 2,47 \\
\hline Hutan Produksi Konversi & $9.587,65$ & 2,90 \\
\hline Hutan Produksi Terbatas & $15.228,08$ & 4,60 \\
\hline Taman Nasional & $10.799,00$ & 3,26 \\
\hline Total & 330.803 & 100 \\
\hline
\end{tabular}

Berdasarkan peraturan pemerintah tentang perubahan fungsi kawasan hutan yang dapat dilakukan pengembangan atau pembangunan adalah fungsi kawasan Areal Penggunaan Lain (APL) yang digunakan diluar kegiatan kehutanan. Luas areal penggunaan lain di Kabupaten Solok juga cukup luas yaitu 118.413,2 Ha atau 35,80\%. Fungsi kawasan hutan lain yang dapat dilakukan pengembangan adalah Hutan Produksi Konversi (HPK) yaitu merupakan kawasan hutan yang secara ruang dicadangkan untuk digunakan bagi pembangunan atau pengembangan diluar kegiatan kehutanan, dengan luas 9587,65 $\mathrm{Ha}$ atau 2,90 \% . Berarti luas kawasan hutan yang dapat dilakukan suatu pengembangan atau pembangunan adalah $128.000,81 \mathrm{Ha}$ atau $38,7 \%$ dan kawasan hutan yang tidak bisa diganggu adalah hutan lindung, cagar alam, danau, hutan produksi, taman nasional, dan hutan produksi terbatas dengan luas keseluruhan $202.802 \mathrm{Ha}$ atau $61,3 \%$.

\section{Penggunaan Lahan}

Penggunaan lahan juga berperan penting dalam menentukan lahan tersedia, karena setiap penggunaan lahan mempunyai fungsi dan kegunaannya masing-masing, ada yang dapat di lakukan perubahan penggunaan lahan dan ada yang tidak dapat dilakukan perubahan. Penggunaan lahan Kabupaten Solok yang diperoleh berdasarkan data dari Badan Litbang Sumber daya Lahan Pertanian tahun 2011, terdapat 11 jenis penggunaan lahan di Kabupaten Solok. Data mengenai luasan berbagai kelas penggunaan lahan tersebut secara rinci dapat dilihat pada Tabel 3.

Tabel 3. Penggunaan Lahan Kabupaten Solok

\begin{tabular}{|c|c|c|}
\hline Pengunaan Lahan & Luas (Ha) & Persentase (\%) \\
\hline Hutan lahan kering & 64359,31 & 19,46 \\
\hline Hutan lahan kering sekunder & 106514,75 & 32,20 \\
\hline Hutan tanaman industri & 1151,87 & 0,35 \\
\hline Semak/belukar & 23266,09 & 7,03 \\
\hline Perkebunan & 358,82 & 0,11 \\
\hline Pemukiman & 3591,70 & 1,09 \\
\hline Tanah terbuka & 1496,49 & 0,45 \\
\hline Danau & 2576,10 & 0,78 \\
\hline Pertanian lahan kering & 58664,63 & 17,73 \\
\hline Pertanian lahan kering campuran & 46012,11 & 13,91 \\
\hline Sawah & 22811,12 & 6,90 \\
\hline Total & 330.803 & 100 \\
\hline
\end{tabular}

\section{Analisis Ketersediaan Lahan}

Fungsi kawasan hutan yang di asumsikan sebagai lahan tersedia adalah fungsi areal penggunaan lain dan hutan produksi konversi. Luas dua fungsi kawasan yang telah diperoleh 
berdasarkan analisis adalah 128.000,81 Ha atau 38,7 \% dari luas Kabupaten Solok (Tabel 1). Sementara dari data penggunaan lahan, yang diasumsikan sebagai lahan tersedia adalah penggunaan lahan yang berpotensi untuk pengembangan kopi arabika, yaitu: hutan lahan kering, hutan lahan kering sekunder, hutan tanaman industri, semak/belukar, perkebunan, pemukiman, tanah terbuka, pertanian lahan kering, dan pertanian lahan campuran dengan luas 301.824 Ha atau 91,23\%. Jadi ada beberapa penggunaan lahan sebenarnya tidak tersedia atau mengganggu komuditas lain, tetapi lebih berpotensi untuk tanaman kopi arabika. Berdasarkan data fungsi kawasan hutan dan penggunaan lahan, maka dari analisis penggabungan kedua data tersebut, diperoleh data ketersediaan lahan untuk pengembangan komoditas kopi arabika seperti Tabel 4.

Tabel 4. Ketersediaan Lahan Pengembangan Kopi Arabika di Kabupaten Solok

\begin{tabular}{|c|c|c|}
\hline Ketersediaan & Luas $(\mathbf{H a})$ & Persentase (\%) \\
\hline Tersedia & $101.059,79$ & 30,55 \\
\hline Tidak tersedia & $229.743,2$ & 69,45 \\
\hline Total & $\mathbf{3 3 0 . 8 0 3}$ & $\mathbf{1 0 0}$ \\
\hline
\end{tabular}

Seperti yang terlihat pada Tabel 4 bahwa lahan yang tersedia di Kabupaten Solok cukup luas untuk melakukan pengembangan suatu komuditas yaitu 101.059,79 Ha atau 30,55\%. Lahan tersedia yang telah dipeoleh belum tentu semuanya cocok dengan kopi arabika, maka dari itu perlu dilakukan lagi analisis kesesuaian lahan untuk kopi arabika dari lahan tersedia.

\section{Analisis Parameter Kesesuaian Lahan Pengembangan Kopi Arabika di Kabupaten Solok}

\section{Ketinggian Tempat (Elevasi)}

Ketinggian tempat atau elevasi merupakan salah satu parameter penting untuk tanaman kopi arabika karena kopi arabika sangat baik tumbuh pada daerah yang mememiliki ketinggian tempat di atas $1.000 \mathrm{mdpl}$ atau di daerah yang dingin. Kabupaten Solok termasuk ke dalam kategori daerah yang dingin dengan elevasi atau ketinggian tempat seperti Tabel 5.

Tabel 5. Ketinggian Tempat

\begin{tabular}{|c|c|r|r|}
\hline Ketinggian Tempat (mdpl) & Skor & Luas $(\mathbf{H a})$ & Persentase (\%) \\
\hline$>2.000 ;<100$ & 1 & $5.288,06$ & 1,60 \\
\hline $1.750-2.000 ; 100-600$ & 2 & $69.785,94$ & 21,10 \\
\hline $1.600-1.750 ; 600-700$ & 3 & $28.782,06$ & 8,70 \\
\hline $700-1600$ & 4 & $226.946,95$ & 68,60 \\
\hline Total & & $\mathbf{3 3 0 . 8 0 3}$ & $\mathbf{1 0 0}$ \\
\hline
\end{tabular}

Peta ketinggian tempat atau elevasi dibuat secara digital, yaitu dengan mengklasifikasikan data SRTM (Shuttle Radar Topography Mission) menjadi data ketinggian tempat dalam satuan mdpl. Berdasarkan Balai Penelitian Tanah, (2011) ketinggian tempat pada daerah penelitian ini dibagi menjadi 4 kategori dengan masing-masing kategori diberi nilai skoring untuk menganalisis kesesuaian lahan. Skor tertinggi diberikan pada ketinggian tempat 700-1600 mdpl karena pada ketinggian ini kopi arabika sangat sesuai sekali untuk tumbuh dengan baik. Dalam pemberian skor pada 4 kategori ini, semakin tinggi nilai skor maka kategorinya semakin baik untuk tanaman kopi arabika. Pada ketinggian tempat Kabupaten Solok skor tertinggi memiliki luasan yang paling luas yaitu 226.946,95 Ha atau 68,60 \%, dengan kata lain ketinggian tempat daerah Kabupaten Solok mendukung untuk pengembangan kopi arabika. Sedangkan skor terendah juga memiliki luasan paling kecil yaitu 5288,06 Ha atai 1,6\%. Pada ketinggian 1.750-2.000; 100-600 mdpl memiliki luas yang cukup besar yaitu 69.785,94 Ha atau 21,1 $\%$, tetapi nilai skor pada ketinggian ini hanya 2 karena ketinggian ini tidak terlalu sesuai dengan tanaman kopi arabika. Jadi secara keseluruhan Kabupaten Solok memiliki potensi yang besar untuk pengembangan kopi arabika dilihat dari segi ketinggian tempat atau elevasi. 


\section{Kelerengan (Topografi)}

Kemiringan dan panjang lereng adalah dua unsur topografi yang paling berpengaruh terhadap aliran permukaan dan erosi. Kemiringan lereng dinyatakan dalam derajat atau persen. Selain memperbesar jumlah aliran permukaan, makin curam lereng juga memperbesar kecepatan aliran permukaan, dengan demikian memperbesar energi angkut air. Selain itu dengan makin miringnya lereng ditambah dengan pendeknya lereng tersebut, maka butir-butir tanah yang terangkut oleh tumbukan butir hujan semakin banyak. Dengan demikian jika lereng permukaan tanah lebih curam dan kelerengan yang pendek maka kemungkinan erosi akan lebih besar persatuan luas (Hidayat, 2000). Peta kemiringan lereng dibuat berdasarkan data SRTM (Shuttle Radar Topography Mission) yang diidentifikasi berdasarkan persen lereng tertampil dengan pengkelasan pada Tabel 6 .

Tabel 6. Kelerengan

\begin{tabular}{|c|c|c|c|c|}
\hline Kategori & Kelas Lereng (\%) & Skor & Luas (Ha) & Persentase $(\%)$ \\
\hline Sangat Curam & $>30$ & 1 & 82584,33 & 24,96 \\
\hline Curam & $16-30$ & 2 & 159699,29 & 48,28 \\
\hline Agak Curam & $8-15$ & 3 & 41940,86 & 12,68 \\
\hline Datar & $<8$ & 4 & 46578,67 & 14,08 \\
\hline \multicolumn{3}{|c|}{ Total } & 330.803 & 100 \\
\hline
\end{tabular}

Pemberian nilai skor pada kelas lereng sama seperti pemberian skor ketinggian tempat dimana skor tertinggi merupakan kategori yang sangat sesuai atau mendukung pertumbuhan tanaman kopi arabika, begitu juga sebaliknya. Berdasarkan Tabel 6, kelerengan daerah Kabupaten Solok lebih dominan curam dan sangat curam atau memiliki lereng $16-30 \%$ dan $>30 \%$ dengan luas $159.699,29$ ha dan 82.584,33 ha, lebih dari $50 \%$ dari daerah Kabupaten Solok memiliki lereng yang curam dan sangat curam. Menurut Balai Penelitian Tanah, (2011) kopi arabika kurang baik tumbuh pada daerah yang curam dan sangat curam karena pada kelerengan tersebut tingkat erosi cukup tinggi. Walaupun wilayah Kabupaten Solok dominan curam dan sangat curam, tetapi ada juga kelerengan yang mendukung walaupun tidak terlalu luas yaitu pada lereng datar dan agak curam dengan kelas lereng < $8 \%$ dan $8-15 \%$ yang memiliki luas $46.578,67$ ha dan $41.940,86$ ha, sekitar $26,76 \%$ dari luas Kabupaten Solok kelerengannya berpotensi untuk pengembangan kopi arabika .

\section{Jenis Tanah}

Secara umum jenis tanah pada daerah penelitian di Kabupaten Solok memiliki empat jenis tanah, seperti: glei humus, latosol, organosol, dan podsolik. Pada Tabel 7 dibawah ini memberikan informasi tentang jenis tanah pada kawasan Kabupaten Solok.

Tabel 7. Jenis Tanah

\begin{tabular}{|c|c|c|c|}
\hline Jenis Tanah & Skor & Luas (Ha) & Persentase (\%) \\
\hline Organosol & 2 & 6259,47 & 1,89 \\
\hline Latosol & 4 & 16572,90 & 5,01 \\
\hline Podsolik & 3 & 39182,02 & 11,84 \\
\hline Glei Humus & 3 & 268788,29 & 81,25 \\
\hline \multicolumn{2}{|c|}{ Total } & $\mathbf{3 3 0 . 8 0 3}$ & $\mathbf{1 0 0}$ \\
\hline
\end{tabular}

Sumber: Badan Pengembangan dan Penelitian Sumberdaya Lahan Pertanian, (2010)

Tanaman kopi arabika menghendaki tanah yang lapisan atasnya $( \pm 1,5 \mathrm{~m})$ gembur, subur, banyak mengandung humus, dan bersifat pemiabel. Tanah dapat berasal dari gunung berapi atau cukup mengandung pasir. Seperti yang terlihat pada Tabel 7, bahwa jenis tanah latosol mempunyai skor tinggi yang berarti jenis tanah ini sangat bagus untuk tanaman kopi arabika dan luas tanah latosol di Kabupaten Solok adalah 16.572,90 Ha atau 5,01 \%. Jenis tanah glei humus pada Kabupaten Solok merupakan jenis 
tanah yang paling luas yaitu 268.788,29 Ha atau 81,25\%, tetapi hanya diberikan nilai skor 3 karena pada jenis tanah ini pertumbuhan tanaman kopi arabika tidak sebaik jenis tanah latosol. Jenis tanah podsolik juga cukup sesuai dengan tanaman kopi arabika dan diberikan skor 3 dengan luas 39.182,02 Ha atau $11,84 \%$. Jenis tanah podsolik merupakan tanah yang memiliki tingkat kesuburan sedang, tanahnya berwarna merah atau kekuning-kuningan, dan mempunyai karakteristik tekstur yang berlempung atau berpasir. Selanjutnya jenis tanah organosol yang hanya diberikan skor 2 dengan luas $6.259,47 \mathrm{Ha}$ atau $1,89 \%$, jenis tanah ini terjadi dari bahan induk organik, seperti gambut dan rumput rawa pada iklim basah dengan curah hujan lebih dari $2.500 \mathrm{~mm}$ per tahun. Sebagian besar tanah ini masih tertutup hutan rawa gambut dan rumput rawa.

\section{Curah Hujan}

Data curah hujan yang digunakan pada penelitian ini adalah data curah hujan sepuluh tahunan dengan lima stasiun menggunakan metode polygon Thissen yang diproses dengan Arc.GIS 9.3. Hasil analisa data curah hujan dapat dilihat pada Tabel 8 . Stasiun curah hujan yang digunakan dalam kawasan wilayah Kabupaten Solok hanya dua stasiun saja, yaitu stasiun Sanin Bakar dan Danau Atas. Berhubung metode yang digunakan untuk mencari sebaran curah hujan adalah metode polygon Thissen, maka stasiun yang diluar wilayah Kabupaten Solok ikut digunakan juga. Stasiun yang digunakan adalah stasiun yang mendekati dan rentang luas poligon memasuki wilayah Kabupaten Solok, yang mana stasiun itu antara lain Buo, Bendung Batang Hari, dan Gunung Nago.

Tabel 8. Sebaran Curah Hujan

\begin{tabular}{|l|l|l|l|l|}
\hline \multicolumn{1}{|c|}{ Stasiun Klimatologi } & $\begin{array}{c}\text { Curah Hujan tahunan } \\
(\mathbf{m m} / \text { tahun) }\end{array}$ & \multicolumn{1}{|c|}{ Skor } & Luas (Ha) & Persentase (\%) \\
\hline Sanin Bakar & 1525,17 & 4 & 79099,9 & 23,91 \\
\hline Bendung Bt Hari & 2603,00 & 2 & 24345,2 & 7,36 \\
\hline Danau Atas & 2742,91 & 2 & 207114,7 & 62,61 \\
\hline Buo & 2832,39 & 2 & 1825,07 & 0,55 \\
\hline Gunung Nago & 4004,82 & 1 & 18418,4 & 5,57 \\
\hline Total & & $\mathbf{3 3 0 . 8 0 3}$ & $\mathbf{1 0 0}$ \\
\hline
\end{tabular}

Stasiun Sanin Bakar yang terletak dalam wilayah Kabupaten Solok diberikan nilai skor 4, karena pada stasiun ini curah hujan tahunannya mendukung pertumbuhan tanaman kopi arabika yaitu $1.525,17 \mathrm{~mm} /$ tahun dengan luas sebaran 79.099,93 Ha atau 23,91 \% dari luas Kabupaten Solok. Curah hujan tahunan tertinggi terdapat pada stasiun Gunung Nago dimana memiliki curah hujan 4.004,82 $\mathrm{mm} /$ tahun dengan luas 18.418,42 Ha atau 5,57 \% dan diberikan nilai skor 1 yang berarti pada curah hujan ini tanaman kopi arabika tidak dapat tumbuh, karena intensitasnya terlalu tinggi. Pada stasiun Danau Atas, Buo, dan Bendung Batang hari masing-masing memiliki curah hujan tahunan 2.742,91 $\mathrm{mm} /$ tahun, 2.832,39 mm/tahun, dan 2.603,00 mm/tahun sama-sama diberikan nilai skor 2 karena pada tinggi curah hujan tersebut kurang baik untuk pertumbuhan kopi arabika, dari ketiga stasiun tersebut yang paling luas sebarannya adalah stasiun Danau Atas dengan luas 20.7114,67 Ha atau 62,61\%. Sedangkan stasiun Buo dan Bendung Batang Hari masing-masing hanya memiliki luas sebaran 1.825,07 $\mathrm{Ha}$ atau $0,55 \%$ dan 2.603,00 $\mathrm{Ha}$ atau 7,36 \%, luas sebaran ini kecil karena kedua stasiun ini berada diluar wilayah Kabupaten Solok.

\section{Evaluasi Kesesuaian Lahan Untuk Pengembangan Kopi Arabika}

\section{Kesesuaian Lahan Aktual}

Kesesuaian lahan aktual merupakan kesesuaian yang dilakukan pada iklim dan kondisi penggunaan lahan sekarang (present land use), tanpa masukan perbaikan pada parameternya dan kesesuaian lahan berguna untuk mengetahui kecocokan kondisi lahan dengan tipe penggunaan lahan tertentu, disini penggunaan lahan yang dimaksud adalah tanaman kopi arabika. Untuk mendapatkan 
kelas kesesuaian lahan, pada masing-masing atribut peta satuan lahan dibandingkan dengan kriteria kelas kesesuaian lahan.

Berdasarkan hasil analisis dengan menggunakan metode skoring dan dengan cara mengoverlay peta ketinggian tempat, peta lereng, peta sebaran curah hujan tahunan, peta jenis tanah dan peta administrasi maka diperoleh peta kesesuaian lahan aktual tanaman kopi arabika Kabupaten Solok berdasarkan ketersediaan lahan yang ditampilkan pada Tabel 9.

Tabel 9. Kesesuaian Lahan Aktual

\begin{tabular}{|l|c|c|}
\hline \multicolumn{1}{|c|}{ Kelas Kesesuaian Lahan } & Luas (ha) & Persentase (\%) \\
\hline S1 (Sangat Sesuai) & $9.476,41$ & 9,38 \\
\hline S2 (Cukup sesuai) & $75.466,81$ & 74,68 \\
\hline S3 (sesuai Marginal) & $16.166,58$ & 15,95 \\
\hline \multicolumn{1}{|c|}{ Total } & $\mathbf{1 0 1 . 0 5 9 , 7 9}$ & $\mathbf{1 0 0}$ \\
\hline
\end{tabular}

Seperti yang terlihat pada Tabel 9, kelas kesesuaian lahan dibagi berdasarkan struktur FAO (1976) dengan S1 (sangat sesuai) memiliki luas 9.476,41 ha atau 9,38\%, yang berarti sekitar 9,38\% daerah Kabupaten Solok sangat sesuai untuk pertumbuhan kopi arabika tanpa ada faktor pembatas yang akan mempengaruhi perkembangannya. Sedangkan kelas S2 (cukup sesuai) merupakan yang paling mendominasi dengan luas 75.466,81 ha atau 74,68 \% yang mana pada kelas ini cukup sesuai untuk perkembangan kopi arabika dengan faktor pembatas dapat diatasi oleh petani sendiri. Untuk kelas S3 (sesuai marginal) pada Kabupaten Solok memiliki luas $16.166,58$ ha atau $15,95 \%$ yang mana pada kelas ini mempunyai faktor pembatas yang dominan dan faktor pembatas ini akan berpengaruh terhadap produktifitas kopi arabika. Untuk mengatasi faktor pembatasnya memerlukan biaya yang tinggi, sehingga perlu adanya bantuan kepada petani untuk mengatasinya. Sedangkan untuk kelas N (tidak sesuai) tidak terdapat pada ketersediaan lahan, jadi secara otomatis pada lahan tersedia hanya kelas S1, S2, dan S3 saja.

Berdasarkan hasil analisis peta kesesuaian lahan dan ketersediaan lahan untuk pengembangan tanaman kopi arabika di Kabupaten Solok dapat diketahui bahwa lahan yang dapat dijadikan kawasan pengembangan tanaman kopi arabika adalah lahan yang tergolong ke dalam kelas kesesuaian lahan S1 (Sangat Sesuai) dan Kelas S2 (Sesuai) dengan total luasnya 84.943,22 ha atau 84,05\% dari luas lahan tersedia . Pada lahan yang dikelaskan dalam kelas S3 (Sesuai Marginal) atau disebut juga dengan kelas lahan kurang sesuai, dilakukan usaha perbaikan agar dapat digunakan untuk penanaan tanaman kopi arabika.

\section{Kesesuaian Lahan Potensial}

Kesesuaian lahan potensial adalah kesesuaian yang diberikan masukan perbaikan atau konservasi pada parameter yang menjadi faktor pembatas (Balai Penelitian Tanah, 2011). Pada penelitian ini parameter yang diberikan masukan konservasi adalah kelerengan dengan melakukan konservasi pembuatan terasering, karena hanya kelerengan yang dapat diberikan masukan perbaikan dari empat parameter kesesuaian lahan dalam penelitian ini. Jadi kelas kelerengan akan dinaikan satu tingkat atau skornya ditambah satu untuk kategori curam dan agak curam, sehingga kesesuaian lahan menjadi seperti yang terlihat Tabel 10 .

Tabel 10. Kesesuaian Lahan Potensial

\begin{tabular}{|l|c|c|}
\hline Kelas Kesesuaian lahan & Luas (ha) & Persentase (\%) \\
\hline S1 (Sangat Sesuai) & $18.79,27$ & 17,89 \\
\hline S2 (Cukup sesuai) & $70.311,89$ & 69,57 \\
\hline S3 (sesuai Marginal) & $12.668,63$ & 12,55 \\
\hline \multicolumn{1}{|c|}{ Total } & $\mathbf{1 0 1 . 0 5 9 , 7 9}$ & $\mathbf{1 0 0}$ \\
\hline
\end{tabular}


Pada kesesuaian lahan potensial, luas lahan kelas S1 (sangat sesuai) meningkat dari 9.476,41 ha atau 9,38\% (kesesuaian lahan aktual) menjadi 18.79,27 ha atau 17,89\%, yang berarti masukan perbaikan pada kelerengan berpengaruh terhadap kesesuaian lahan untuk pengembangan kopi arabika di Kabupaten Solok. Sedangkan kelas S2 (cukup sesuai) dan kelas S3 (sesuai marginal) masing-masing mengalami penurunan luas dari 75.466,81 ha $(74,68 \%)$ menjadi $70.311,89$ ha $(69,57 \%)$ dan $16.166,58$ $(15,95 \%)$ menjadi $12.668,63$ ha $(12,55 \%)$, yang berarti pada kelas ini kelerengan banyak diberikan masukan perbaikan konservasi terasering sehingga banyak kelas S2 (cukup sesuai) yang naik ke kelas S1 (Sangat sesuai), begitu juga dengan kelas S3 (sesuai marginal) yang naik ke kelas S2 (cukup sesuai).

Berdasarkan hasil analisis peta kesesuaian lahan potensial dan ketersediaan lahan untuk pengembangan tanaman kopi arabika di Kabupaten Solok, dapat diketahui bahwa lahan yang dapat dijadikan kawasan pengembangan tanaman kopi arabika adalah lahan yang tergolong ke dalam kelas kesesuaian lahan S1 (Sangat Sesuai) dan Kelas S2 (Sesuai) dengan total luasnya 88.391,16 ha atau $87,46 \%$ dari luas lahan tersedia. Jadi perbedaan luas kesesuaian lahan aktual dan potensial yang telah diberikan masukan perbaikan pada kelerengan adalah 3.447,94 ha atau 3,41\% dari luas lahan tersedia.

Menurut Puslitkoka (2004), bahwa kopi arabika menghasilkan sekitar 1 ton untuk setiap 1 ha lahan per tahunnya. Luas kesesuaian lahan aktual S1 dan S2 untuk pengembangan kopi arabika di Kabupaten Solok berdasarkan lahan tersedia adalah 84.943,22 ha, dengan asumsi produktifitas 1 ton/ha/tahun maka Kabupaten Solok akan menghasilkan kopi arabika sekitar 84.943,22 ton/tahun. Untuk kesesuaian lahan potensial yang telah diberi masukan perbaikan konservasi terasering pada kelerengan kelas S1 dan S2 memperoleh luas 88.391,16 ha, maka dengan asumsi produktifitas 1 ton/ha/tahun tersebut kopi arabika yang akan dihasilkan adalah 88.391,10 ton/tahun.

\section{KESIMPULAN}

Luas lahan tersedia yang diperoleh di Kabupaten Solok cukup luas yaitu 101.059,79 ha atau $30,55 \%$ dari luas wilayah Kabupaten Solok. Dengan adanya lahan tersedia tersebut didapatkan juga kesesuaian lahan aktual untuk pengembangan kopi arabika kelas S1 dan S2 seluas 84.943,22 ha (84,05 $\%$ ) dari luas lahan tersedia, dengan asumsi produktifitas kopi arabika 1 ton/ha/tahun Kabupaten Solok bisa menghasilkan kopi arabika sekitar 84.943,22 ton/tahun. Untuk kesesuaian lahan potensial yang telah diberi masukan perbaikan konservasi terasering pada kelerengan, luasnya bertambah 3.447,94 Ha $(3,41 \%)$ sehingga luas kelas S1 dan S2 menjadi 88.391,16 ha $(87,46 \%)$ dari lahan tersedia.

\section{DAFTAR PUSTAKA}

Balai Penelitian Tanah. 2011. Evaluasi Lahan Untuk Komoditas Pertanian. Pusat Penelitian dan Pengembangan Tanah dan Agroklimat. Bogor

FAO. 1976. A Framework For Land Evaluation. Soil Resources Management and Conservation Service Land and Water Development Division. FAO Soil Bulletin 32. Rome, Italy.

Saragih, Jef Rudiantho. 2010. Kinerja Produksi Kopi Arabika dan Prakiraan Sumbangannya dalam Pendapatan Wilayah Kabupaten Simalungun. VISI (2010) 18 (1) 98 - 112.

Puslitkoka. 2004. Panduan Lengkap Budidaya Kopi. Pusat Penelitian Kopi dan Kakao. Jember, Jawa Timur. 